\title{
O Impôsto de Lucro Imobiliário e as Vendas de Bens Imóveis Adquiridos Mortis Causa
}

\author{
ARNOLD WALD
}

\begin{abstract}
Q UANDo surgiu o impôsto de lucro imobiliário, a Fazenda quis tributar a diferença entre o preço de aquisição e o preço de venda de determinado bern imóvel. Uma das primeiras polêmicas que se desenvolveram em tôrno do assunto foi a referente ao caso de aquisições mortis causa. Entendia a Fazenda que, no caso de bens adquiridos por herança, o impôsto de lucro imobiliário, tomaria como base a avaliação do bem no inventário. Os tribunais não foram unânimes em sufragar tal entendimento. As leis fiscais, diziam, não admitem a interpretação analógica. Em relação aos bens adquiridos por herança, não há na realidade um lucro pois não houve preço de custo e a avaliação no inventário não pode ser equiparada a compra e venda.
\end{abstract}

Acórdão líder na matéria foi aquêle publicado na "Revista Forense", vol. 152, p. 185 e oriundo do Tribunal Federal de Recursos. Era a seguinte a sua ementa:

"O impôsto criado pelo Dec.-lei n. ${ }^{\circ} 9.330$, de 1940, não incide sôbre os imóveis havidos "mortis causa". 1946."

Inteligência dos arts. $10^{\circ}$ e $2 .^{\circ}$ do Dec.--lei n. ${ }^{\circ} 9.330$, de 10 de junho de

Foi relator do Acórdão, o Ministro Cunha VASConcelos, tendo apresentado voto vencido o Ministro JoÃo José DE QueIrós. Em seu voto, o Ministro ELMANO CRUz apontava a finalidade do tributo, dizendo que visava "limitar as especulações em tôrno da propriedade imobiliária, ou pelo menos fazer com que os especuladores repartissem com o fisco parte dos polpudos lucros que vinham abiscoitando. Não teve por escopo aquêle texto de lei (Dec.-lei n. ${ }^{\circ}$ 9.330) querer gravar tôdas as situações anteriores, por ocasião da alienação posterior da propriedade imóvel, e muito menos proíbir ou restringir a livre circulação das riquezas."

O legislador, estranhando a reação jurisprudencial, quis garantir de melhor maneira os interêsses do fisco. Assim é que a Lei n. ${ }^{\circ} 2.354$, de 29 de março de 1954, ao regulamentar o imnôsto de renda, referiu-se especialmente no art. $92 \S 5 .^{\circ}$ à matéria. Declarou então que:

"Nos casos de venda de imóveis havidos por herança, será considerado como valor de custo o que constar do laudo de avaliação nos autos de inventário..." 
Mas a jurisprudência não se deu por vencida. Continua atendendo mais à mens legis, à razão da lei do que a sua letra. $\mathrm{E}$ assim os tribunais continuam a considerar injustificada e injustificável a cobrança do impôsto de lucro imobiliário quando onera bens adquiridos por herança.

Em recente sentença, o Dr. Juiz em exercício na $1 .^{a}$ Vara da Fazenda Pública lembrava que:

"A lei visou, como se verifica dos seus motivos e da própria letra, tributar a especulação imobiliária - fonte de enormes lucros, fator de inquietação econômica, sem qualquer proveito para a coletividade, fazendo reverter em benefício desta o que só era ganância, interêsse egoístico de particulares. Ora, os bens deixados por herança refogem a essa qualificação e não se enquadram, de modo nenhum, na odiosa exploração da indústria imobiliária, objeto do tributo. Não há como sujeitá-los ao impôsto impugnado". (Diário da Justiça de 17 de março de 1956, p. 2.956).

O problema continua aberto, despertando o interêsse e a atenção dos estudiosos que atendem à natureza do conflito entre o fisco e a proteção dos direitos individuais. 